\section{Mashudu C. Mashige}

Mashudu Mashige holds a D.Litt et Phil degree in English literature from Rand Afrikaans University, Johannesburg. He is senior lecturer in the Department of English at the University of Venda, where he teaches African and English Literature.

E-mail: mashigem@univen.ac.za

\title{
Identity and culture in Mi S'dumo Hlatshwayo's worker poetry
}

\section{Identity and culture in Mi S'dumo Hlatsh- wayo's worker poetry}

Through an examination of selected poems from Mi S'dumo Hlatshwayo's oeuvre, this article examines the role of worker poetry in the construction and articulation of a "worker identity". The article furthermore examines the worker movement's attempt, through this poetry, to present alternative symbols through an oppositional culture and confrontational performance. Drawing from a wealth of rural and urban poetic traditions, worker poets also redefine the power dynamics characterised by the relationship between the oppressor and the oppressed, the powerful and the powerless, typified in the employer-employee relationship to articulate their identity in their own terms. Key words: identity, culture, performance, poetry.

The last two decades of the twentieth century have seen the concept of cultural identity receiving close attention from scholars in the fields of literary criticism, Sociology, Psychology and Political Studies. The common denominator amongst these fields of study is their attempt to conceptualise cultural identity and thereby provide an analytical frame of reference within which individuals and societies can define themselves. While the conceptualisation of cultural identity is central to these fields, it is also important to point out that each field has its unique manner of articulating identity, influenced by theoretical imperatives as well as historical particularities and the political power dynamics at play at any given moment. Within these contextual contingencies, theorists take the peculiarities of their circumstances and use these as tools to help analyse their identity.

Chantal Mouffe problematises the question of identity by locating it in a political context within which there is competition between the conceptualisation of identity in respect of individuals and in respect of citizens. The challenge, Mouffe contends, lies in trying to ensure that such a conception does not sacrifice the one to the other. There is a need to ensure that belonging to different communities of values, language and culture should manifest in a manner that is "compatible with our common belonging to a political community whose rules we have to accept" (Mouffe 1995: 34). What seems to be a solution to these vexing challenges is to conceive a sense of commonality that not only accepts practical differences, but also goes further to respect 
such variation and open a space for different forms of expressing individual identity. The concept of identity necessarily invokes similarity and difference. It involves a form of cultural encounter that allows for the representation of sameness within the context of otherness. Acknowledgement of similarity and difference opens up space for a multicultural perspective and creates a terrain of critique in which the absolutisation of culture and difference can be avoided. This understanding of identity illustrates, furthermore, how social relations and identities are always constructed through what Mouffe (1995: 44) calls "asymmetrical forms of power", which, of course, problematises the notion of a harmonious or unitary national identity.

Decontextualised, the question of identity can never be fully operational. Such a context is culture. In attempting to define what culture is, Immanuel Wallerstein begins by pointing out culture's inherently paradoxical nature and character, a paradox that finds expression in the binary interplay between its particular and its universal points of reference. He sees culture as a set of values or practices of some part smaller than some whole. This is true whether one is using culture in the anthropological sense to mean the values and/or the practices of one group as opposed to any [other] group at the same level of discourse or whether one is using culture in the belles-lettres sense to mean the "higher" rather than the "baser" values and/or practices within any group, a meaning which generally encompasses culture as representation, culture as the production of art forms (Wallerstein 1991: 91).

Seen from either perspective, culture encompasses, on the one hand, what and how some people do or feel about certain affairs as opposed to those who may not feel or do anything about the same things. This is what is called culture's particular point of reference. On the other hand, there is acknowledgement that cultural values and practices are validated when predicated upon a universal matrix. Within this context, Wallerstein (1991: 92) warns against the essentialisation of the values and practices of particular groups as this may lead to "an absolutely paralyzing cultural relativism (since the argument would hold equally for any other group's values and/or practices) or to an absolutely murderous xenophobia (since no other group's values and/or practices could be good and therefore could be tolerated)". His assertions suggest that culture should never be thought of in terms of absolute diversity. Instead, diversity should include a certain correlation "between cultures", what Bhabha (1996: 53) calls "culture's in-between". It is this "in-between-ness" of culture that has to be seen as important in the articulation of identity.

The polarities of identity and culture also immure the polarities of inside and outside, self and other, personal and political, subjective and objective. What becomes clear, is that identity operates under erasure, implying, to this end, that it is never fixed, as its construction and articulation are contingent upon the context within which an individual finds him/herself, hence its strategic and positional nature. In contrast to this, culture is often regarded as fixed and stable, and as embodied in 
political abstractions, such as traditions, values, practices and customs, all of which are tied to the political project of nationalism in the form of, for example, cultural nationalism. Where identity is more about the inward and subjective, culture emphasises the social and the other. It can be argued, however, that the polarities are not mutually exclusive, as culture is implicated in the articulation of identity. The polarities do not exclude culture as a field of subjective experience in which identities can be operationalised. In other words, the relationship between identity and culture is mutually interpenetrative and dialectical.

Throughout the years, South African poetry has expressed, in diverse ways, the socio-political realities of the time, enabling a process of interaction between the personal and the public. Poets are engaged in poetic activity within multiple sets of circumstances. These circumstances have far-reaching implications for the poetry produced. A closer examination of South African poetry in English shows an eclectic range of influences on different poets. These influences largely reflect the intricate nature of South Africa's socio-political and economic make-up. Influences include not only positional influences consequent upon the material realities of everyday life, but also ideological influences, such as, amongst others, liberalism, Black Consciousness, Marxism, nationalism and feminism. These influences have implications for the poetry, though they are not simply reproduced as undigested systems of selfidentification. As a form of symbolic representation, poetry disrupts the linear approach of other forms of expression, through metaphors, symbols, syntax and other stylistic effects. Consequently, poetry provides an opportunity to disrupt pre-given identities in the hope of providing forms of identification more suited to actual human needs. In other words, poetry provides space for the articulation of identity within a dialectical context of self and other, private and public, personal and political. Against this background, this article attempts to examine the manner in which South African worker poetry negotiates cultural, economic and political differences in the creation and articulation of identity out of heterogeneous influences. Worker poets' responses to the aforementioned circumstances of positionality and ideology help shape their poetry and, to a large extent, influence content, style and tone. This, coupled with the individual poet's vision, contributes to the shaping of identity.

In the 1980s South African society witnessed a militant political reawakening contemporaneous with the resurgence of trade union activity on the labour front. In the political arena, the period became characterised by harsh repressive activity that turned South Africa into a virtual police state. The apartheid government, weary of the defiant mood that had begun to engulf the country, surged into overdrive mode, ruthlessly suppressing all voices of dissent and further eliminating almost everything and everyone perceived to be a threat to the security of the apartheid state and its repressive machinery. This ruthlessness also translated into union-bashing activities and the proscribing of individuals. Freedom of association and movement were 
systematically eroded. The whole of South Africa, with its conflict and tension, was in a restive state. Within the labour force, the state's suppressive activities resulted in the revival of trade unions, which hitherto had been dormant due to repressive government policies. The trade union movement saw itself as an integral part of the larger drive for socio-political, cultural and economic transformation in South Africa. It is within this context that a "new" breed of poets emerged. These poets, who were to become known as worker izimbongi (worker poets) made an impact on South Africa's literary production and political transformation. Cognizant of the artistic viability of this poetry, critics, such as Kelwyn Sole (1994: 2) have highlighted the fact that worker poetry as an artistic form of expression has been "bred and nurtured" amongst "ordinary people". Sole argues that this artistic development, which took place in spite of adverse conditions, was initially ignored or scorned by South Africa's cultural elite. It only began to capture the imagination of the literati after it had been adopted and popularised by workers' organisations as a form of cultural expression. Sole (1994: 3-4) succinctly captures this when he observes:

Generally, it has taken the renewed interest in working-class culture generated by the trade union movement in the last decade to challenge this [scorn], just as it has taken the rise of groups using indigenous musical and dance forms to convince intellectuals and cultural agents that such popular forms and preferences are a crucial area of identification and enjoyment for the majority of South Africa's people, and not just a form of ethnic crypto-apartheid masquerading in cultural form.

The poets, called worker izimbongi, because of their identification with workers' struggles and aspirations, gave oral renditions of their poetry in trade unions' mass meetings as well as at mass funerals of political activists. These were the only avenues available for worker poets' and black people's general expression of political aspirations and dissent against apartheid. Consequently, the worker poetry movement thrived to the extent that a rally or a funeral was considered incomplete if it did not have space for a worker poet's oral rendition.

While the worker poetry movement is located within a deeply materialist matrix, where poets oscillate between the oratorical, the local, the heroic and the ordinary in an attempt to locate and articulate their identity as an exploited working class in South Africa, there is evidence of other influences, such as Christianity and the oral tradition. In his seminal study of oral poetry and performance, Duncan Brown traces the influence of Christianity on worker poetry to the days of Isaiah Shembe, a messianic Zulu evangelist and founder of the Church of the Nazarites. Through his church, Shembe sought to revive Zulu social customs and mores. He, ultimately, syncretized "the belief systems of Zulu tradition (which are directed primarily towards social concerns) with those of Christianity (which are more abstractly theological and future-directed), and by hybridizing the Christian hymn with Zulu poetry 
and song, he created forms which expressed religious and political resistance to colonial oppression" (Brown 1998: 120).

The poetry focuses on worker solidarity in its attempt to present alternative symbols through an oppositional culture and confrontational performance. It aims at presenting social alternatives to what workers see as an extremely repressive and exploitative status quo they have to help change. Workers thus see their poetry as having social relevance within the broader context of struggle politics. By focusing on the day-to-day challenges that workers have to contend with, and through performance, worker poetry attains both its contextual significance and socio-political significance. Michael Chapman (1992: 512) sees this as poetry, the mimetic affirmations of which "are related directly to life and, therefore, have narrative power in the real social world". The poetry is further defined through the quality of its "intensified utterance and incantation". To understand the poetry's relevance and how it attempts to articulate a workerist identity, it is important to always respond to the "text" in tandem with the poet-activist in the context of the call for cultural liberation, a call that "cannot take place outside the broader struggle for a democratic South Africa" (Chapman 1992: 521). The foregoing quotations suggest that another inherent quality of worker poetry is its desire to democratise not only South Africa but South African culture as well. This entails speeding up the interaction and interpenetration of various cultural art forms, the encouragement of more public and communally based art forms and the "transformation of experiences of art, culture and identities" (Sole 1994: 5) in the emergent South African culture that allows and celebrates a multiplicity of voices.

Worker poetry is accessible and efficacious in its articulation of workers' struggles. It further has a general political slant geared towards contributing to change in South Africa. This poetry also draws heavily from what was mistakenly thought to have been an extinct oral tradition. This tradition, characterised chiefly by praises, employs a number of poetic devices, such as imagery, symbolism, satire and parallelism. To a very large extent, it is these devices that present worker poets and ordinary people with a platform through which to voice their struggles and thereby, hopefully, reclaim public space in the struggle for freedom and their desire to articulate identity within a unique context of social and political struggle. This opens space for worker poets to act as repositories of popular memory and consciousness by recording the history of the workers' struggle. Worker poets thus find the art of izibongo a viable form of articulating the aspirations of workers in general. While the worker poetry movement was largely dependent on the labour movement for its reinvigoration, worker poets further recognised the significantly important role that poetry had to play in the process of cultural reclamation central to South Africa's transformation and identity politics. In essence, worker poets realised that they could not divorce themselves from the larger struggle for political, economic and cultural freedom that was going on in South Africa. Thus, they saw theirs as being both a workers' struggle 
and a struggle for the emancipation of South Africa's oppressed majority. This was informed by the workers' understanding of the Marxist perception that puts the worker movement in the vanguard of socio-economic and political transformation. It is important to point out that the materialist matrix upon which worker poetry is based is the same matrix in which poets of revolution, such as Jeremy Cronin and Peter Horn, amongst others, locate their construction of identity. The question that may arise is why an attempt is made here to distinguish between two categories of poetry that predicate their conception and articulation of identity upon a similar ideological premise. An assiduous examination and reading of the two categories of poetry reveals that whilst both move from the same socialist point of departure, poets of the revolution have in common, besides their adherence to Marxist theory, academic backgrounds that enable them to engage with issues from a theoretically nuanced perspective as they raise the reader's consciousness towards understanding the material function of literature in the construction and articulation of cultural identity. Worker poets, within the context of South Africa's historical reality, are largely black proletarians generally characterised by limited skills arising from the fact that the majority of them only have basic literacy and numeracy. Thus their poetry tends mainly to focus on issues they contend with daily as they battle to eke out a living and to seek solidarity as a class of exploited workers.

Equally important is worker poetry's approach and tone in redefining and transforming the power dynamics characterised by the contrasting relationship between the oppressor and the oppressed, the powerful and the powerless, typified in the employer-employee relationship. This the poetry does by drawing from a wealth of poetic traditions, some of them already highlighted above, which make it challenging to compartmentalise this poetry into any one specific category or nomenclature. As correctly averred in the introduction of Izinsingisi: Loud Hailer Lives, in worker poetry the reader can detect influences of "the Nguni oral tradition, the Christian Bible, the black-consciousness poetry of the 1970's, jazz poetry just as [one] can pick the rhythms and imagery of street talk" (Sitas 1988: ii). These are the influences that imbue the poetry with a quality of linguistic accessibility and enable it to touch the ordinary person, to whom the poetry is primarily directed. The poetry's accessibility contributes, largely, to its assertiveness in articulating South Africa's socio-political and economic realities, particularly the realities facing workers defying a system that engineered to exploit, subjugate and dampen their steadfastness and will to survive. Worker poetry is, furthermore, replete with a sense of urgency, vivid immediacy and a forthrightness that encapsulates the workers' determination to survive despite the harsh conditions that the political and labour realities visited upon them. It is this determination that makes workers and worker poets recognise and reassert the centrality of cultural identity in the broader national struggle for political emancipation, succinctly encapsulated in the following declaration: 
Because, even if we are culturally deprived as workers, we demand of ourselves the commitment to build a better world (...). This makes us say that it is time to begin controlling our creativity: we must create space in our struggle - through our own songs, our own slogans, our own poems, our own artwork, our own plays and dances. At the same time, in our struggle we must also fight against the cultural profit machines. (Sitas 1986: 59-60)

The above declarations describe the importance attached to the role played by cultural identity in the struggle for a new South Africa. Workers and worker poets assert the indispensability of culture in the political and economic transformation of society as well as in the articulation of identity. What worker poets do through the above declaration is to assert that they, too, as the proletariat, can and will make their contribution to the articulation of a workers' identity, and that the process of articulating any form of cultural identity through art in South Africa should not be left in the hands of the bourgeois class. The declaration, furthermore, warns workers against abdicating their responsibility of challenging apartheid power structures. It bears testimony to the determination and disposition that worker poets have towards what they consider a very important task of transforming South African society. Through the declaration, worker poets display their desire to rid themselves of the mentally imposed manacles and the apartheid exploitation that had become characteristic of South Africa's exploitative labour laws. Their avowed desire is nothing less than the total extirpation of oppressive institutions in the quest to build a new country embracing just, caring and collective principles of equality for all its inhabitants, a society in which internationalist values of solidarity would prevail. The foregoing qualities are evident in the work of Mi S'dumo Hlatshwayo, which forms the central focus of this analysis.

Born in Cato Manor, Durban, in 1951, Hlatshwayo grew up a so-called illegitimate child in a poor working-class household in a shack settlement, which was also known as $M^{\prime}$ 'kumbane. His family's financial difficulties forced him to abandon his formal education at a very early age while he was still doing standard seven, or Grade 9 in today's parlance. Leaving school was a major blow that almost turned his dreams into nightmares. As he told Fosatu Workers News with his leaving school all his dreams were sunk:

I wanted to be a poet, control words, any words, that I might woo our multicultured South Africa into a single society. I wanted to be a historian of a good deal of history; that I might harness our past group hostilities into a single South African history. (...) After 34 years of hunger, suffering, struggle, learning and hope, I am only a driver for a rubber company. (Hlatshwayo 1985: 35)

Hlatshwayo's determination, however, saw him continue with self-education through reading whatever he came across. He joined the St. John's Apostolic Church, the 
eCibini, after he had been healed from a serious illness (Sitas 1986). In this independent African church whose members were generally poor, he experienced the acceptance, concern and care he had never experienced before. This was a church without distinction or status, where ordinary people shared and prayed together. Through the church's emotional gatherings where men and women had integrated the imbongi tradition of Nguni traditional poetry, Hlatshwayo began to discover the power of language and poetry. This he carried with him into all levels of life. He ultimately joined MAWU (Metal and Allied Workers' Union) where he was catapulted into cultural activism. After listening to Alfred Temba Qabula reciting his poetry, Hlatshwayo realised that he did not need formal tertiary education to write poetry. This realisation brought him closer to Qabula who also strongly believed that poetry, as Brown (1998: 221) puts it, "was not the sole preserve of specific members of society". He composed "The Black Mamba Rises" to praise the Dunlop workers' struggle. He teamed up with Qabula and others to form the Durban Workers' Cultural Local. This strengthened their belief that poetry was public property. For example, Qabula once asserted that one of his main aims was to redress the generally held notion that poetry belonged to "amaintellectuals" (Gunner 1989: 51). In collaboration with fellow worker poets Qabula and Nise Malange, Hlatshwayo published Black Mamba Rising: South African Worker Poets in Struggle in 1986. Izinsingisi: Loudhailer Lives, South African Poetry from Natal, a collaborative effort by Hlatshwayo, Malange, Qabula, Naidoo, Ndzimande and other worker poets was published in 1988. Ari Sitas edited the two anthologies.

In Hlatshwayo's “The Black Mamba Rises” (Sitas 1986: 25) from which the anthology Black Mamba Rising derives its title, there is evidence of the poet's skilful use of oral traditional literary forms. In the poem, Hlatshwayo, like other worker poets, acts as a repository of popular memory and consciousness by recording the history of the struggle for workers. Hlatshwayo regards the izibongo as a viable form for articulating the aspirations of the workers, as illustrated in the comment, "it was here, amid the spontaneous singing which marked all worker gatherings, that I saw the possibilities of refashioning the traditional oral praise poem to articulate the struggle of the workers" (Oliphant 1989: 42). The statement has important cultural significance as it lays a foundation on which traditional oral forms of expression are merged with the workers' socio-political aspirations in the quest for a new society and new forms of identities. It also illustrates that workers and worker poets have a role to play within South Africa's cultural identity politics. That Hlatshwayo sees the possibility of refashioning a new poetry from the traditional oral form is evidence of the workers' need for articulating their conception of cultural identity within the broader arena of cultural reclamation. The statement constitutes another building block in the path towards cultural, social and political renewal and reclamation.

The poem itself opens with a vivid description of "victors of wars" who "then retreat" and "The builders of nests" who "like an ant-eater (...) then desert" and finally 
"leave the employers / unnerved". The above description initially evokes and engenders a vague sense of unease in the reader. It is only when the reader realises that the description is a build-up to the unveiling of the poem's central image, the black mamba, that things become clearer. The black mamba is a symbol for the resurgence of the black workers' trade union movement that the reader is able to put the mamba within the social and political context of struggle against apartheid exploitation and oppression. In the poem, this analogy of the revival of unions is evident in the following lines from the poem's sixth stanza:

It was stabbed good and proper

During the day,

At Sydney Road right on the premises

To the delight of the impimpis,

And the delight of the police

There were echoes of approval on the

TV at Aukland (sic) Park saying:

Never again shall it move,

Never again shall it revive,

Never again shall it return,

Yet it was beginning to tower with rage.

The rising mamba, putatively dead, engenders tensions and anxiety for those initially happy with its destruction. Suddenly, they have to face up to the challenges posed by the mamba with its recharged might. That the revival of the mamba represents the resurgence of trade union militancy is accentuated by the obvious discomfort of employers upon realising that they had misjudged the situation entirely. This is reinforced by the parallelism in "Never again shall it move, / Never again shall it revive,/Never again shall it return," which is ironic, for, contrary to expectations, the mamba begins "to tower with rage". The employment of the mamba imagery, a direct borrowing from the animal imagery characteristic of izibongo, reinforces the majestic qualities of the union. From an aesthetic perspective, the borrowing also marks a departure from the idea of poetry being private property. It becomes public property whose aim is to help engender an atmosphere within which workers can begin to articulate their own identity in their own terms, something highlighted in the workers' declaration earlier on in this discussion. This can be seen as a form of cultural democratisation, the aim of which is to spread knowledge beyond an elite few to enable workers to participate, on their own terms, in the production of a culture that will form part of their identity. It is, furthermore, important to note here that the poet applies a propagandistic approach through which he wishes to uphold that which is acceptable to the labour movement whilst simultaneously discouraging, that which is unacceptable. This inaugurates a process in which workers reclaim their voice and 
space within the context of the employer-employee discourse. This also illustrates the fact that the discourse on identity becomes a contested terrain and that the contestation has a lot to do with the fact that, for worker poets, the main issue is, first and foremost, the important one of liberating workers from racial-capitalistic exploitation and, subsequently, of asserting their right to articulate their identity either as individuals or as a collective. Employers now realise that they can never supplant the workers' desire for fair and democratic representation in their quest for dignity and identity. They become aware that workers will always fiercely resist an identity imposed from without, an identity that does not open a window to self-definition. Through the revival of unions, workers have set the tone for the forging of a new worker culture on the factory floor. Tension is heightened by the multiplicity of unions that arise out of the initial one employers had thought was totally crushed. This is evident in the seventh stanza of the poem where the persona describes the revival of trade unions, in a mischievous tone that almost borders on contempt for employers, thus:

The old mamba that woke up early in the

Morning at St Anthony's

On rising it was multi-headed,

One of its heads was at Mobeni,

Njikazi, the green calf of

MAWU can bear me out

Another of its heads was at baQulusi

Land at Ladysmith,

On rising it was burning like fire.

That the union has risen with ferocity and that its influence in the labour sector is pervasive, causes consternation amongst employers. The image of a burning fire in the last line of the stanza underscores the influence, militancy and vigilance of the resuscitated unions. Through the image, the dragon-like qualities of the rising mam$\mathrm{ba}$, the persona's obvious allusion to the mythical many-headed hydra, are also attained thus encapsulating the workers' desire to continue asserting their human dignity in their fight against all forms of exploitation, deliberate dehumanisation, cultural malignancy and malicious othering. Cognizant of this newfound power, even the most pertinacious of employers, typified in the poem by the ruthlessly unscrupulous Sikhumba, realise that things cannot go on as usual. The persona makes the same observation in the eighth stanza when he maintains:

But he is now showing a

Change of heart

Let's sit down and talk, he

Now says. 
Hlatshwayo employs several images to buttress his conscientising message. Whilst the mamba is the leitmotif for the poem, there are other equally important images that accentuate the process of cultural reclamation, even if only by drawing deeply on cultural forms. The buffalo, for example, is another powerful image that is used in the poem in consonance with the spear and the dangabane weed. This is evident in the following:

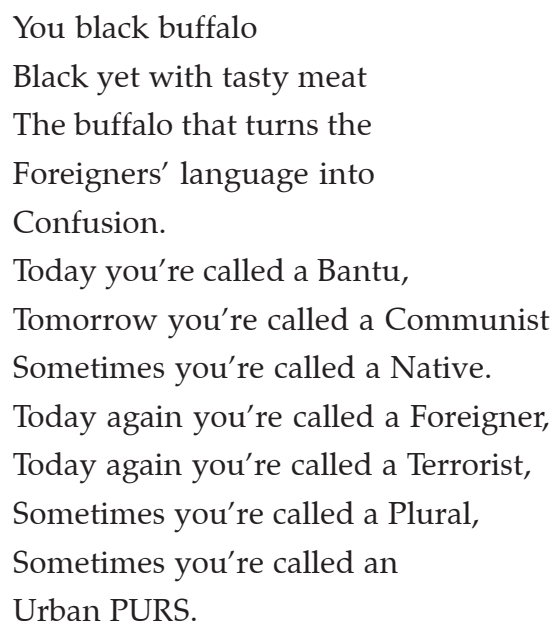

The imagery of the black buffalo is significant in this respect, particularly when viewed against the apparent confusion it brings. This image, suggestive of vitality, suppleness and a combative spirit, is meant to catalyse workers into action. The image also highlights the dichotomy inherent in the employer-employee relationship. On the one hand, the buffalo is seen as objectionable by the white employers because of its black colour and strength, while on the other hand, the selfsame employers need the labour of the black buffalo. The stanza also resonates with the tragi-comic nomenclature that characterised the inflexible ideology underpinning apartheid South Africa. In their effort to confine blacks to the periphery of economic activity, successive apartheid governments fragmented the country into linguistic and tribal enclaves called homelands. From these satellite homelands, the white captains of South African industry could tap cheap labour. Consequently, black South Africans were disenfranchised, alienated from and deprived of their South African citizenship in favour of a dubious homeland citizenship. This, in essence, meant that black South Africans were subjected to a process in which they had enforced identities imposed upon them as a result of the government's political agenda: to impose its own versions of identities on the whole country.

However, because industry needed black labour, new categories were invented to legitimise black labourers in what had effectively become "white South Africa". Among the many laws enacted to enable whites to procure cheap black labour was a law 
acknowledging the existence of Permanent Urban Residents (PURS). When the black populace in urban areas became restive, a concoction of names and excuses was invented. When Blacks demanded dignity and the recognition of their cultural practices as essential defining characteristics of their South Africanness, "Communists" and "Terrorists" were invariably blamed. Throughout the poem, the persona highlights the curious dichotomies of the then South African situation, dichotomies that further illustrate the contradictions inherent in the government's policy of institutionalised racism. As Mala Singh (1997: 120) rightly observes: "Apartheid was a powerful allocator of identity. It assigned identity through legislation and other sanctions. It suppressed identity - through centralising race and ethnicity at the expense of other markers of identity. It facilitated identity through unifying its opponents in a common assertion of non-racialism."

It is not surprising that towards the end of the penultimate stanza in "The Black Mamba Rises" the persona apprises the reader of the inevitability of the resurgence of black trade union movements symbolised in the poem by the black mamba. The employment of the mamba metaphor is deliberate so as to enable the audience and reader to deduce the resurgent union's vigilance by drawing an analogy between the unions and the venomous qualities of the black mamba. Coupled with this are the ferocious qualities of the buffalo, which then add to the strength of the revived unions. The revival of unions does not only represent the revival of the struggle for workers' rights but transcends the narrow confines of the workers' floor to become representative of the broader struggle for the assertion and articulation of identity and black cultural reclamation.

Through the use of izihasho (peer praises) in "The Black Mamba Rises", Hlatshwayo skilfully infuses a satirical slant into the poem:

Ngudungudu, the woman

Who married without any

Lobolo,

Busy boiling foreigners'

Pots

Yet yours are lying cold.

The name Ngudungudu is used here as a term of endearment, but it is downplayed by the persona who, instead of praising the subject, chastises her for the folly of giving herself free of charge to the employers whilst her own homestead remains unattended. Of interest is the use of the lobolo imagery. Lobolo is a cultural practice of paying money or cattle for a bride. Its aim is to strengthen kinship between the families of the bride and the groom. Therefore, a woman who marries without lobolo is seen in the eyes of society as a lesser woman. As a matter of fact, no culturally sensitive and selfrespecting woman would want to be married without lobolo primarily because, in 
rural communities, great store is placed on the marital status of women. Here the persona uses the lobolo image to buttress the folly of selling one's labour cheaply, just like a woman who does chores when she knows that her husband has not paid lobolo for her. In the end Ngudungudu busies herself "boiling foreigners' / Pots" while those of her husband "are lying cold". Hlatshwayo successfully employs satire to highlight and ultimately reinforce the inherent irony within this particular situation. As adumbrated earlier, Hlatshwayo draws from a wealth of cultural material and tradition to buttress the points he makes in his poetry. Hlatshwayo's use of izihasho is particularly significant in that they are used to strengthen an individual's sense of belonging to a community and cultural group. As Judith Coullie (1999: 72) correctly points out:

the praise poem (...) is a statement of identity in community, its appeal lying in social anchoring and the pleasures of performance and the performer, whether that be the subject of the poem or not, and the auditors. Instead of a developmental depiction of subject, of a self split between the private, interiorized "real" and the public persona, the self in oral poetry is addressed as a knowable, stable and unified entity. The subject is hailed, interpellated, known, through the praises, to him/ herself and to members of the community. Instead of the economy of personal revelation, of individualised confession, oral forms rely on communalism, on shared knowledge and ritual, on conformity and concord.

Hlatshwayo uses available literary works as his point of departure in highlighting and reinforcing salient points. In the last half of the sixth stanza quoted earlier, for example, he says:

There were echoes of approval there on the

TV at Aukland (sic) Park saying:

Never again shall it move,

Never again shall it revive,

Never again shall it return,

Yet it was beginning to tower with rage.

The poet is echoing a section from Nyembezi's poem (1960) to Shaka from “Izibongi zika Shaka" in which the poet avers:

The jest of women of Nomgambi,

Jesting while enjoying the sun,

Saying Shaka shall never rule,

Shall never be king,

Yet he was beginning to flourish. ${ }^{1}$

At the same time, there are further traces of Nyembezi's (1960) "Izibongo zika Dinizu$l u$ ", in the following lines from the fifteenth stanza of "The Black Mamba Rises": 
Run in all directions

Stand on top of the mountains,

Report to Botha at Pretoria

Report to our heroes on the

Island,

Report to the angels in your

Prayers,

Say unto them - here is a

Flood of workers

The employers have done what

Ought not to be.

These lines echo Nyembezi's lines:

Run in all directions

Tell the people of Sidladla and Ntini

And those of Vuma

Not to drink the waters of the Mkhize River

Because Dinizulu has done what ought not to be done.

"The Black Mamba Rises" is, therefore, a tribute to the workers that draws heavily on historical antecedents, such as the izibongo tradition to locate the workers' struggles within the broader struggle for the forging of identities and the (re)construction of new forms of cultural identification. The poet deliberately draws on traditional oral forms to reject the conception that traditional oral forms, which are a constituent part of African identity and culture, are devoid of educible patterns for socio-cultural and political reconstruction. By borrowing deeply from traditional oral forms, the poet brings poetry to a public platform in the hope of making it more accessible to ordinary people. Thus poetry is removed from the domain of private property accessible only to academia and a few other individuals, and becomes the public property of the people, property that helps them in their quest to articulate their cultural identity firstly, as the working class and secondly, as members of the movement towards democracy. In this way, the poet adds weight to the argument that culture, as represented in this instance by poetry, has a significant role to play in social transformation and the articulation of communal identity.

In the poem "We Workers Are A Worried Lot" (Sitas 1986: 32), Hlatshwayo continues with his consciousness-raising process. This time the immediate target of his vitriol is the "racist oppressor". The poem opens with a warning to the "racist" about the psychological state in which the workers generally find themselves. The title itself suggests a greater element of anxiety and restiveness on the part of the workers. This is the persona's primary concern throughout the poem. The persona presents 
the ideals cherished by workers, which include the desire to fight against "injustices", "unemployment", "starvation", and the quest "to gain peace" and "win equality". However, workers become worried upon realising that their point of departure and frame of reference are diametrically opposed to those of the "racist oppressor". This immediately creates the occasion for confrontation as the two parties run on an ideological collision course with no apparent possibility of backing down as is evident towards the end of the first stanza, where the persona realises and illustrates the differences as he avers:

Kodwa Hawu!

To you, our friends

Are foes!

To you, our foes

Are Friends!

We workers are a worried lot.

The quoted section highlights the source of the workers' discontent. They operate in a hostile environment where their values are antithetical to those of their employers, who were defined as "racist" in the beginning of the poem. The second stanza of the poem is a wake-up call to the "racist oppressor", a warning for him/her to realise that time is running out. The persona also attempts to narrow the obvious ideological chasm and conceptual differences between employer and employee. He exhorts the employers to take off their ideologically tinted spectacles and to see things from the workers' perspective. This message is taken over to the third stanza of the poem where the persona calls for a concerted effort to "wave off/Mass dismissal" and "stave off / Mass unemployment". This call has far-reaching implications for the relationship between employers and employees. Within the context of South Africa's historically deeply racialised divide, a society in which employment or unemployment was essentially the dividing line between blacks and whites, such a call would obviously evoke interest from different perspectives and quarters. This is largely because South Africa had been divided into two sections, whites who were a minority, generally well-off as employers, and blacks, who were a majority, generally poverty stricken with a small percentage of them employed. It is against this background that the persona calls for the staving off of "mass unemployment". Furthermore, the persona realises that for the country to remain peaceful there is a need to pacify the majority and also to ensure that mechanisms are put in place for equity and justice. It is within this context that the persona evokes the names of Helen Joseph, tireless veteran of the democratic struggle in South Africa, Neil Aggett, trade union leader and secretary of the Food and Canning Workers' Union (Transvaal) who died in detention in 1982, and Neil Alcock, agrarian self-help activist killed during attempts to create peace amongst warring factions at Msinga, Kwazulu, all of whom are called "disciples of 
justice". The persona describes them as such, because while all of them were white and thus belonged to a privileged class, they chose the path of justice by being actively involved in workers' struggles and in the broader struggle for liberation, some of them paying the ultimate price: losing their lives in the quest for democratic liberation and justice. It is also interesting to note at this stage the persona skilfully bringing in an important reference to identity and identification as he avers:

Yes, in Africa
Let us be Africans
Fear is a fallacy
Now

Let us touch on your untouchable sacred ground

To be forged by FOSATU

To struggle in CUSA

What a march

Of people's congresses

To come!

The message that the persona brings to bear in the first five lines of the quoted section has significant implications for the construction and articulation of identity. Apartheid was based on colonialist and separatist notions of white superiority. Thus, the majority of white South Africans continued to see themselves as overlords to the black people. They saw themselves as masters who had to subjugate the African by suppressing his "heathen culture" and destroying his "barbaric identity". Through this understanding, everything associated with Africa was, therefore, inferior and vile and had to be destroyed. The direct consequence of this mentality was the binary division between black and white. In this division black was seen as the "other" that needed to be supplanted. Flowing from this understanding the majority of white South Africans continued to see themselves as Europeans in Africa despite the fact that their families have been living in the continent for three centuries. This is what the persona challenges. He calls for identification with Africa by revealing that those who want the continent to succeed have nothing to fear in identifying themselves as such. The persona further attempts to reassure those for whom the mere mention of Africa conjures up the misery of poverty, hunger, war and death that their fear needs to be replaced with a determination to unite in the quest for liberation to rid Africa of its negative colonial legacy.

The importance of unity is further buttressed in the fourth stanza where the persona calls for united action in staving off "Star Wars". Instead the persona wants unity towards building "empires without/Bombs", putting "power in maize fields / Not missiles", giving "respect to God and not/To dollars" so that "even the soil/Shall sing praise hymns". Through these sharp antitheses, that invert contemporary materialis- 
tic and militaristic values, the persona calls for a new united and collective approach towards addressing social and political problems. He calls for action in developing the continent. The persona sees this as the only way to restore country and continent. He warns against continued wars and calls for peace. He attacks the obsession with wealth, typified by the dollar, at the expense of spirituality. The persona illustrates that through united action people can foster a sense of identification with country and continent. Anything short of this results in the fragmentation of people into artificial racial categories, a fragmentation that perpetuates divisions and strife.

The fifth stanza of the poem opens with lines in parallel construction with the opening lines of the first stanza. However, the tone and content of this stanza are different from those of the first stanza. Where the first stanza focuses on the fight against injustices and exploitation, the fifth stanza focuses on the positive qualities inherent within the African continent. What the persona does is to invite those who are committed to a non-racial South Africa to join him on a path of discovery as he posits:

We can discover

The secrets of Africa

The splendour of Africa

We can discover

The pride of Africa

Covered by the sand dunes

Of exploitation

Covered by the sand dunes

Of colonialism

And Maye!

Africa

The Eden of nations

The pillar of the universe

Shall now lead the world

From its hunger

From poverty

- Of minerals

- Of morals

- And love

Workers are a worried lot.

The above stanza is quoted in full, because the persona makes a significant number of assertions in it that have a direct bearing on the reclamation of Africa's values and the general reconstruction of the continent. The use of the word "discover" in the third 
line of the stanza has profound implications. It suggests that Africa still has inexhaustible hidden wealth that even colonialism could not ravage. The use of the collective pronoun "we" immediately suggests a co-operative arrangement in the restorative process of discovery. The persona seems to be suggesting to the "racist oppressor" that if they join hands together in the process, benefits will accrue to both of them and to the continent as a whole. This, in essence, is a turning away from the confrontational and oppositional tendencies that generally characterised the employer-employee relationship. In this instance, a hand of friendship is extended to the oppressor because the oppressed are cognizant of the importance of conciliation in the quest for the restoration of Africa. Thus, the situation becomes a microcosm of what the rest of the continent should follow. Ultimately, it transcends the narrow confines of the binary opposition between employer and employee to become representative of the larger need for national and continental co-operation. The persona suggests that through this co-operation people can discover the "splendour" and "pride of Africa" that hitherto had been covered by "the sand dunes" of a racially conceived "exploitation" and "colonialism". The use of words such as "discover", "covered" and "dunes" suggests an element of blindness that had made it impossible for the oppressor to recognise the "splendour" and "pride" of Africa. As it is, the persona suggests that it is only through working together with the oppressed that the oppressor can be redeemed from his psychological and spiritual blindness, a pervasive blindness that hinders the cultivation of meaningful relationships between people, who by virtue of their geographical situation are supposed to be compatriots.

The second half of the stanza describes Africa as "The Eden of nations / The pillar of the universe". On the surface, this assertion looks superficial, stereotypical and overstated. But closer scrutiny is quite revealing. The assertion highlights that Africa has indeed been an Eden, because of its rich raw resources. In its former unadulterated state, the continent epitomised the unalloyed beauty, almost in a romantic sense, of rusticity before the advent of colonial exploitation. The statement further points to Africa being the cradle of humanity. Recent palaeontological discoveries reinforce the continent's Edenic character in the historical development of the human species. Of interest is the persona's assertion that Africa, which has become typically known as a basket case because of its internecine wars and famine, "Shall now lead the world / From its hunger / From poverty". It is worth noting that, despite the negativity that has become associated with Africa over the years, the persona is still able to see the good that Africa can contribute towards universal human development. It is ironic that a continent generally associated with internecine wars, malnutrition, genocide and poverty is now portrayed as the potential saviour of a new world. This is illustrative of the persona's commitment to Africa and his deliberate aim of focusing on the good that can come out of Africa. The persona seems to subscribe to the notion that because Africa has seen the worst in suffering, it can only improve. 
Finally the persona qualifies the poverty from which Africa can deliver the rest of the world. It is poverty "of minerals/ of morals/And of love". The invocation of morals in parallel with minerals suggests that morals are the minerals of a good life. It further points to the importance of moral and ethical behaviour in the quest for material wealth. The implication here is that throwing away morals in pursuit of profit and material wealth leaves individuals ethically bankrupt and spiritually empty. What the persona advocates is the pursuit of wealth in such a manner that its acquisition is beneficial to the individual and the rest of society and not only for the elite. This is the message that the persona wants the "racist" to hear. He believes that once this reality has dawned upon the "racist", there will be a greater possibility for better human interaction that may lead to a greater understanding of humanity's mutual interdependence. This understanding would lead, hopefully, to acceptance of difference not as a problem to be overcome but rather as a platform that provides individuals with an opportunity for interaction and interfacing in the construction and articulation of cultural identity.

Worker poetry in general has a propagandist slant as it aims to uphold and propagate that which is deemed acceptable by workers in their struggle for social, political and cultural emancipation. This the poetry does by addressing issues that are pertinent to the workers' struggle and that contribute towards the transformation of South African society. Hlatshwayo, a representative of worker poets, also uses his poetry not only to mobilise workers and to document their struggles, but also to offer a sociopolitical critique of the South African situation. Through his skilful borrowing from traditional oral forms such as izihasho and izibongo, Hlatshwayo uses his poetry to articulate a worker-centred vision of an egalitarian South Africa that will be without exploitation and oppression. This, coupled with a desire to ensure that the articulation of workers' identity is never ignored within South Africa's political and cultural discourses, is what Hlatshwayo and worker poets in general set out to do. The history of the liberation struggle, an important weapon in the arsenal of worker poets, is used to instil a sense of urgency in the message that the poet communicates. As an ardent student of liberation history, Hlatshwayo taps from such aspects of history into which he infuses elements of the heroic to conscientise the workers into action. Ultimately, this marks the beginning of a process towards cultural reclamation, which he hopes will eventually usher in the articulation of new forms of cultural identity.

The foregoing analyses clearly illustrate that Hlatshwayo, as representative of worker poets, draws from a wide range of poetic and cultural experiences to present poetry which seeks not only to articulate a worker identity but also to present an alternative socio-political and economic system. Through his poetry the poet starts a process whose ultimate goal is the creation of a collective, workerist self-image of South Africa. The poetry draws strongly from the izibongo and izihasho traditions to ultimately relocate poetry from a deeply private domain to the public domain of the ordinary person. What becomes indubitable is the fact that by working from a deeply 
materialist matrix, and drawing deeply from both the oral tradition and Christianity, worker poets recognise the importance of articulating their own sense of culture and identity within the context of South Africa's struggle politics. By forging a workers' identity within the broader context of South Africa's socio-economic and political emancipation, worker poets also highlight the centrality of culture in the construction and articulation of identity.

\section{Note}

1. My thanks to Sandile Ndaba for permission to use the English translation of Nyembezi's "Izibongi zika Shaka" and "Izibongo zika Dinizulu" from his article (Ndaba 1999).

\section{Bibliography}

Berold, R. (ed.). 2003. South African Poets on Poetry: Interviews from New Coin 1991-2001. Scottsville: Gecko Poetry.

Brown, D.M. 1998. Voicing The Text: South African Oral Poetry and Performance. Cape Town: Oxford University Press.

Chapman, M. 2002. The New Century of South African Poetry. Johannesburg, Cape Town: Ad Donker.

Chapman, M. et al. (eds.). 1992. Perspectives on South African English Literature. Parklands: Ad Donker.

Coullie, J. 1999. Dislocating Selves: Izibongo \& Narrative Autobiography in South Africa. In Brown, D. (ed.). Oral Literature and Performance in Southern Africa. Oxford: James Currey.

De Kock, L. 2001. South Africa in the Global Imaginary: An Introduction. Poetics Today 22 (2): 263-298.

Derrida, J. 1974. Of Grammatology. Trans. G.C. Spivak. Baltimore: The John Hopkins University Press.

Fosatu Worker News. 1985. 35, June.

Kromberg, S. 1993. The Problem of Audience: A Study of Durban Poetry. Unpublished M.A. thesis. Johannesburg: University of Witwatersrand.

1994. Worker Izibongo and Ethnic Identities in Durban. Journal of Literary Studies 10 (1): 57-74.

Mashige, M.C. 1996. Politics and Aesthetics in Contemporary Black South African Poetry. Unpublished M.A. thesis. Johannesburg: Rand Afrikaans University.

2004. Identity, Culture and Contemporary South African Poetry. Unpublished D.Litt et Phil dissertation. Johannesburg: Rand Afrikaans University.

Mouffe, C. 1995. Democratic Politics and the Question of Identity. In Rajchman, J. (ed.). The Identity in Question. London: Routledge.

Ndaba, Sandile C. 1999. Tradition and Innovation: The Uses of Oral Traditional Forms in Mi Hlatshwayo's Poetry. Voices: A Journal for Oral Studies 2: 37-47.

Nyembezi, C.L.S. 1960. Izibongo Zamakhosi. Pietermaritzburg: Shuter and Shooter.

Oliphant, A.W. 1989. Culture and Organisation in the Labour Movement. Staffrider 8 (3 \& 4): 29-35.

Raditlhalo, S.I. 2002. Who am I? The Construction of Identity in Twentieth-Century South African Autobiographical Writing in English. D Litt. dissertation. Groningen: Rijkuniversiteit Groningen. <http: www.roggels.dds.nl.tmp/whoami.pdf> Accessed: 15 November 2004.

Singh, M. 1997. Identity in the Making. South African Journal of Philosophy 14 (3): 16-32.

Sitas, A. (ed.). 1986. Black Mamba Rising: South African Worker Poets in Struggle. Durban: Culture and Working Life Publication.

(ed.). 1988. Izinsingisi: Loudhailer Lives, South African Poetry from Natal. Durban: Culture and Working Life Publication.

Sole, K. 1994. Democratising Culture and Literature in a "New South Africa": Organisation and Theory. Current Writing 6 (2): 1-37.

Wallerstein, I. 1991. The National and the Universal: Can There Be Such a Thing as World Culture? In King, A.D. (ed.). Culture, Globalization and the World-System: Contemporary Conditions for the Representation of Identity. London: MacMillan. 